\title{
Mulla Sadra and Evolution Theory
}

\author{
ALI ARSHAD RIAHI*, MOHAMMAD NASSRISFAHANI \& MEHDI JAFARZADEH ${ }^{1}$
}

\begin{abstract}
In their observations, contemporary scientists have believed in transformism which claims whole natural world is always in evolvement. This paper investigates whether Mulla Sadra's philosophical opinions are consistent with this theory or not. The method of this research is analytical-descriptive. The conclusion is that four fundamentals: the principality of existence, the analogical unity of existence, the substantial movement and gradual increase in intensity of existence, are the main foundations of Mulla Sadra's philosophy. The first three principles justify the forth one which is 'the evolutional movement of the natural creatures'. According to Mulla Sadra, nature is in-itself a movement and movement is not limited to accident, but he believes that movement is the mood of the nature. He believes that nature is, therefore, a continuous whole that moves from its inferiority to its superiority, in the same way as a child grows. In this paper it is also proved that the evolution of the creatures does not contradict the existence of God and religious texts.
\end{abstract}

Keywords: evolution, evolution theory, Mulla Sadra, transformism

Have the component parts of the world of nature - the inanimate, plants, animals, and human being - been the same from the beginning of the universe or one is a changed form out of another, i.e. a change from the inanimate into plants, from plants into animals and from animals into human beings? There is a general point of view which can be traced back to the time prior to Socrates, the myths of China and ancient India that the universe, as it is now, was suddenly created with its biodiversity and each of the four parts of nature - the inanimate, plants, animals and human beings - are created and vanished repeatedly. No evolution is seen in their type and essence, and the only changes have been seen is superficial. In this universe, human soul alone has had an opportunity to exist before, or being created at the same time together with the body and when the body attached to it, decays, it always survives by itself (Mulla Sadra 1383Ha). Most of the Moslem philosophers believed the same idea called 'Fixism'. As the history of science has frequently proved, scientists belong to a more immense culture, the ideas of which affect the inquiries they believe important. It also affects the categories with which they interpret or explain their knowledge and the certainties governing their attitudes. So, the interpretation of religious books by theologians is based on theses cultural teachings.

Evolution is a new theory upon which the whole world of nature changes so that the whole universe, or some parts of it, is always under constant and increasing change, and in the process of the development, number, variety and complexity of the parts of the world are increasing. Buffon (1707-1788) and Lamarck (1744-1829) in the eighteenth century were the

\footnotetext{
${ }^{1}$ Ali Arshad Riahi*(Corresponding author), Ph.D., Associate Professor at Department of Philosophy and Theology, University of Isfahan, ISFAHAN, Iran, email: arshad@ltr.ui.ac.ir; Mohammad Nassrisfahani, Ph.D. candidate at Department of Philosophy and Theology, University of Isfahan, ISFAHAN, Iran; Mehdi Jafarzadeh, Lecturer at Language Centre, University of Isfahan, ISFAHAN, Iran.
} 
pioneers of evolution theory in biology, but Darwin (1809-1882), in the nineteenth century, by offering various documents made this theory testable. The first theories were simple, obscure and less scientific but, little by little, it became more stable and today, very few people don't believe in the theory of evolution (Encyclopedia of the Islamic World 1383H), and even it is irrationally generalized to other areas (Bowler 2000). Although the theory of evolution, either from philosophy or science point of view, has had a recording ancient Greece and among the Muslims such as Ikhwan al-Safa (Ikhwan al-Safa 1995) and the philosophers like Ibn Miskawayh $(1338 \mathrm{H} ; 1365 \mathrm{H})$, its discussions have become controversial, in the new era, and as a scientific theory, from the beginning of its proposal, have encountered agreement and opposition especially by some religious people (Bowler 2000). Unfortunately, the theory of evolution has not been discussed seriously from Islamic philosophy point of view. The ancient philosophies such as Platonism, Aristotelianism, peripateticism and the school of illumination cannot answer the questions regarding the relation between natural creatures and the theory of evolution, but this theory not only can be in the same category with Mulla Sadra's geometry knowledge but they are congruous and one who believes in Mulla Sadra's geometry knowledge cannot oppose the evolution of creatures, including human being. This article is going to prove that Mulla Sadra's philosophical thought not only is in agreement with the theory of biological evolution but it is its requirement. Mulla Sadra (1572/ 1640), in the seventeenth century, had stated some aspects of this theory prior to the biologists like Bowfin, Lamarck and Darwin. After offering a brief sketch of biological theory of evolution, this article is trying to investigate the congruency of Mulla Sadra's thoughts with it and will explain his philosophy in defining the evolution of the species.

\section{Theory of Evolution, a Sketch}

Many ancient philosophers believed that God created the universe at once, and in the same way as present time, and all species have always been the same. The theory of the evolution of the natural creatures, of course, was discussed as a theory, more or less, among the Roman, Greek and Muslim philosophers. The inquiries if species are invariant but guilds are in evolutionary development and whether species evolve and the evolution of species and guilds results from themselves or directed by the supernatural are the issues that some of the Muslims were engaged in the past. So, according to Islamic philosophers, the theory of evolution is a philosophical theory, rather than a scientific-experimental one, and its principles are completely rational. However, theory of evolution which is the result of the observations made by empirical scientists was introduced in the eighteenth century by scientists like Darwin and Wallace (Ville 1979).

According to Darwin's evolution theory, all species of animals and plants have gradually, continuously and impalpably changed from the first form into a new one (Darwin 2004). Being involved in twenty years of endeavour and collecting evidence, Charles Darwin arranged his theory and compiled it in his book called The Origin of Species in 1859 (Campbell 1971). He offered some evidences like the function of human choices in changing different species while growing flowers, plants and domestic animals. According to him, natural changes that rarely happen in different species of plants and animals, the internal and external attempts of every creature to survive as well as the chance of survival of the most of the small and useful changes compatible to the suitable conditions are triple grounds for creatures to evolve. Happening of these changes in suitable external conditions differs their durability to the changes; for example, the animals living near the sea from those living on the land, the animals living in the deep area of the sea from those living in the shallow area and the animals living exposed to light from those exposed to less light are noticeably different (Darwin 2004). From his point of view, plant 
and animal growers do the same with plants and animals as nature does. The theory that Darwin and Wallace formulated on that basis (at first, independently of each other) may be stated as four propositions and three deductions. Both propositions (p) and deductions (d) have since been well corroborated by careful observation:

P.1. Organism produce a far greater number of reproductive cells, and, indeed, young individuals, than ever give rise to mature individuals.

P.2. The number of in individuals in populations and species remains more or less constant over long periods of time.

D.1.Therefore there must be a high rate of mortality both among reproductive cells and among immature individuals.

P.3. The individuals in a propositions are not all identical but show variation in all characters, and the individuals that survive by reason of their particular sets of characters will become the parents of the next generation.

D.2.Therefore the characters of those surviving organisms will in some way have made them better adapted to survive in the conditions of their environment.

P.4.Offspring resemble parents closely but not exactly.

D.3.Therefore subsequent generations will maintain and improve on the degree of adaptation realized, by gradual changes in every generation (Campbell 1971).

As Darwin (2004) admitted, his theory was with some problems which had to be solved and accomplished in later studies by others who did it. The concept of animate evolution can be traced back to the ancient Greece but the invention of microscope and the investigation on the classification of the living things have helped it improve. The approach of transformation and basic changes in the process of proving the theory of evolution in the eighteenth century owe the scientists like Mendel, Maupertuis and Diderot (Mussaheb 1380H, V. 2). Slow and long-term evolution processes of living things have been proved through studying fossils (Prothero 2011). Nowadays, the theory of evolution has noticeably improved and the issue of mutation is proposed which is due to the radiation of x-ray, gamma and some chemicals and gives rise to genetic changes in living things.

According to this theory, the origin of life on the earth began with a simple protoplasm layer, probably in the sea, and after a long time appeared in the form of plant, animal and human being (Villee 1979). The successive periods have been time for Protozoan species, simple invertebrates, fish, amphibians, reptiles, dinosaurs, birds, mammals and eventually human-like creatures and primates. The most interesting is the discoveries that may result in the missing rings of the immediate ancestry of man. Australopithecus is the oldest that lived in south Africa about one million years ago and because of the size of its brain, form of scull, kind of teeth and a, more or less, straight stature was a creature between monkey and new man. There are some evidences showing that this creature had used some very simple tools (Campbell 1971).

Sahelanthropus in China, like Pitcanthropus in Java and Homoerectus dating back to half a million years ago, had a brain smaller than human brain, more or less, a smooth forehead, relief jaws and straight stature. This creature made use of fire and hard tools. Although Swanscombe's brain was downward, it had a completely improved figure and was from 250000 years ago. But Neanderthalensis man dating back to the era after the beginning of the last ice age, still had raised eyebrows, protruded jaws and wide bones. Finally, some discoveries, such as Cro-Magnon that used to paint, hold funeral ceremony, and regarding form and culture was completely Homo sapiens, belonged to 50000 years ago (Campbell 1971). 


\section{Mulla Sadra's Geometry Knowledge}

The principality of existence, the analogical unity of existence, the substantial movement and gradual increase in intensity of existence are four institutional principles of Mulla Sadra's philosophy. These four principles have made a framework and a special epistemic system for Mulla Sadra who observes the universe and man through it. The first three principles are an introduction to the fourth one. As those three principals have always been discussed in philosophical works, this paper discusses only the fourth one.

\section{Graded Increase in Intensity of Existence}

Movement is meaningless without a direction and it must be towards a point or aim. There is nothing outside existence towards which the caravan of existence to move. So, the material world will forcefully be changing from the inanimate into plants, from plants into animals, from animals into human being and from human being into intellect. This change can occur in two ways: one way is destroying the previous form and making a new one and therefore a gap occurs between them. The second way is occurring a new form onto the old one which will not result in any break, but the intensity of material existence will increase. The philosophers such as Ikhwan al-Safa and Ibn Miskawayh (died $421 \mathrm{AH}$ ) did not believe in the gap between the creatures and while rejecting substantial movement, they pointed to this evolutional joint as: 'the end of each species joins the beginning of the next species as a single fact' (Ibn Miskawayh $1338 \mathrm{H})$.

Affected by philosophical dominated culture, Mulla Sadra called the curves of descent and ascent the cycle of existence (Mulla Sadra 1381H). He believes that in ascending movement all creatures of the universe become attentive to the Truth and the Highest Good. He believes everything, whether intellects, souls or material things, move to the Highest Origin. This movement and natural attraction to the obedience of The Primal Cause is the innate religion and the natural belief of the creatures moving towards the Truth (Mulla Sadra 1381H). The difference between Mulla Sadra and others is that he believes the world of nature is one single continuous thing, reaching from its inferiority to its superiority, like a child's reaching puberty, going through adolescence and becoming perfect. Departure, destination and mover are the same. It begins from itself, moves in itself and reaches to itself. The difference between 'intensive movement' and 'generation and corruption' is that former is wearing after wearing but the latter is doffing after wearing.

Mulla Sadra has joined substantial movement to principality and unity of existence and says that every object has a special existence which is original and is, by itself, determined and distinguished. This existence possesses unity besides positions and degrees. There are several attributes for each degree and position. He believes that the existence is continuous and gradually changes from potentiality into actuality. Whole essence and substance is being renewed and every object is changing and this movement is the cause for all accidental movements (Mulla Sadra 1383Hb). According to Mulla Sadra (1378H) the stability of species is acceptable as far as we are concerned with subjective consideration because genus species and specific difference are abstract and mental. They do not exist in reality in determination. The creation of universe with all it contains from the sky to the earth is gradual and along with changing and developing existence and at every moment they are in new creation. Mulla Sadra $(1383 \mathrm{Hb})$ insists on the idea that existence is always increasing and its substance is moving. Ipseity always exists and the present ipseity contains the previous ones. In other words, the previous ipseity increases. 
Therefore, philosophy can be divided into two categories: being philosophy and becoming philosophy. The philosophies of Ibn Sina, Farabi and others are of the kind of being philosophy and Mulla Sadra's philosophy is becoming philosophy. The active philosophy of Mulla Sadra believes in priority and posteriority for external things, i.e. each one of immaterial things, plants, animals and man has ranking priority over another: human temperament is reached after gaining animal temperament and animal temperament is achieved after reaching plant temperament and also plant temperament is gained after achieving corporeal form and the matter carrying it (Mulla Sadra 1391H). As Imam Khomeini says one who observes sperm and ignores the forms and the process of changing sperm into human being and suddenly pays attention to the appearance of human being does not believe their relationship. But if he pays attention to the last degree of the previous stage to the last part of its development, he will never say that this is not that. In being philosophy, the whole category of plant, animal and human is considered one species, but in becoming philosophy of Mulla Sadra every individual is an independent species (Ardabili 1390, v.1).

Mulla Sadra has found and introduced the missing ring which is the mediator of changing each stage into the next. Substance increases and decreases through movement. If there is no increase or decrease, then there is no degree between them which is common between the degrees that are the last degree of intenseness for some and the first degree of weakness for some others. For example, steam is held in common between the air and water. So, when the substance of water changes into air, it gets so tender that it becomes the last degrees of water and the first degrees of air. Mulla Sadra has found missing rings among the creatures through his practical evidence. He has announced that coral is the common denominator and moderate between the inanimate being and the plant, and Waqwaq is the intermediate between the plant and the animal, and monkey is the common denominator and intermediate between animal and human being (Mulla Sadra 1391). Apparently Waqwaq was the name of a tree in an island in China from Palm species with fruits resembling man (Mussaheb 1380). All the biologists, from the seventeenth century onward, have tried to demonstrate, is whatever Mulla Sadra had tried to prove. As if they have followed his works. It is important to notice that Ibn Miskawayh (died in 421) studied the same subject more than 600 years prior to Mulla Sadra (died in 1050) and Mulla Sadra, as it was usual before, without mentioning his name, used a lot of his ideas in his book called Tahdhib al-Akhlāq, (Purification of Morality) and quoted the empirical evidences from him. Here, it is necessary to discuss the subject in detail in order to clarify Mulla Sadra's opinion on evolution.

\section{Evolution in Inanimate Beings}

Mulla Sadra speaks about the issue of fact appropriate with the knowledge of his time in this way: if we look at the inanimate beings from the lowest one to the highest one, the concluded result is that prime matter exists in the lowest part of existence. It is, merely, the potentiality and gets more perfect by accepting material form. So, the specific forms of simple elements which are dust, water, fire and air occurs upon the prime matter. Here, Mulla Sadra explains the distinction between his and others ideas in this way that he believes that dust, water, fire and air possess priority and posterity and are not in the same degree. According to him it is difficult to distinguish the orderliness. He thinks that these four elements are simple and subject to vanish and their combination will give rise to substance. Substance is in a higher position, more resistant and is the intermediate and mediator for other numerous objects. The more intense are these elements, and the more effects they accept, the higher position they ascend to. According to this criterion, the position of the objects like chalk, depilatory and ammonium 
chloride is lower but the degree of some are higher to get to coral and the like. According to Mulla Sadra $(1381 \mathrm{H})$, between each one of them, there are numerous types and classes.

\section{Evolution in Plant Categories}

Mulla Sadra believes that inanimate being gets so developed, and becomes so intense that it takes the form of plant. Growth and decline are the effects of the existence of plants. Plants do not merely keep their inanimate condition, but according to their special nature, attract substances and twist them into their own form and make themselves improved. There is difference in quantity, quality, multiplicity, intensity, graduation and linkage in plants. Some of them are close to the inanimate and don't need seeds to preserve their species and a combination of water, dust, sunlight and wind is enough for them to grow. The more perfect plants need seeds to multiply and some of them reach the third stage of evolution and get close to the degree of the animal. They are noble plants, such as olive, vine and Indian almond. These plants are not distinctive due to their masculinity or feminineness. Finally, the evolution process gets close to the animal, so that if it develops a bit more, it will leave plant condition and become an animal. These plants are masculine and feminine. So, the plants like palm tree with ten features resemble animals and only cannot leave the ground to search for food (Mulla Sadra 1381H). Mulla Sadra in his book Shawahid speaks of Waqwaq instead of palm tree as a moderate between plant and human, as it was stated, it is also from palm species and its fruit resembles human being. All Mulla Sadra discuses about plants had already been mentioned by Ibn Miskawayh and the only difference is in some samples. Ibn Miskawayh (1338) believes in the plants like olive tree, pomegranate tree, pear tree, apple tree, fig tree and vine as the mediator between plants and animals but he says that palm tree is in a superior position, closer to the animal, and he finally refers to some similarities between palm tree and animal.

\section{Evolution in Animal Classifications}

Regarding evolution of animals, Mulla Sadra writes that plants take perfection forms one after the other and become gradually perfect. According to him, instinct, sense of pleasure and pain appear in animals. They take pleasure when they meet their interest and suffer pain when they miss it. They enjoy divine inspiration to direct to the good and get aware of the evil. So they move towards the good and avoid the evil. According to Mulla Sadra, animals are in degrees of existence. Some degrees are close to plant and some to human being. The animals, such as worms, flies and insects, which do not mate are weak creatures. Then, superiority increases in them and thereby angriness appears in them. If their angriness is stronger, their armament will be with more strength and if it is weaker, their armament is with less power and enjoys the power of escape or cunning to get rid of danger. Some more perfect animals which are closer to human being have the power of mating, desire to have offspring, try to survive, nourish and grow their offspring and make shelter. These attributes increase to get closer to the human degree. Here, they get the power of learning and training in order to get trained like trained horses, dogs or eagles. Monkey is the most superior among animals which is very close to human being. It is so intelligent that it can imitate human behaviour after watching him and does not need education. When animals pass this stage, they change into human being (Mulla Sadra 1381). Mulla Sadra (1383Ha) believes that the closest animals to plants are those with only one sense and that is the sense of touching; like sponges and mussels, through their voluntary contraction and expansion we can realize such a power in them. This is something somehow seen in plants which react to the growth obstacles or to the reduction of light and change their direction. 


\section{Creation and Perfection of Human Soul}

One of the important results of Mulla Sadra's substantial movement is emerging soul out of material substance. It means when material substance evolves enough and reaches the moderate and appropriate animal temperament and develops into final animal perfection, if it gets a little existential tense it leaves the animal nature and will become capable of thinking, talking and distinguishing and will have human body and figure and will get power with which it can make perfection stages. Having reached human soul, people possess degrees and positions. Some are closer to animals and some to angels (Mulla Sadra 1381). Imam Khomeini's statement on Mulla Sadra's opinion is that this embryo is the material substance already existed and has moved to form brain which is the most moderate object. Brain is so moderate and delicate that is the crown for nature objects and the last nature moderate object and this is the last degree of material substance which has moved in its substance and changed into the first degree of sensation which is touching. This touching power moves, gets strength to gradually form other sensations (Ardaibi 1390, 3). According to Mulla Sadra, human soul, before joining the body, neither as Plato said was in the world of similitude, nor as Aristotle, Ibn Sina and Suhrawardi said was an abstract being that because of appropriate temperament was created and joined the body, but the substance of soul and its nature, from the initial time of joining the body to the last moment of being in the body, is a single reality. Soul is initially nothing; as Quran says: "Did not it happen to human being when he was nothing?". Then, soul in the process of its perfection moves so that it becomes active intellect (Mulla Sadra 1383Hb, 8). Mulla Sadra $(1383 \mathrm{Hb})$ says, it is so difficult to recognize human being that it needs insight and subtle initiative to understand that human being survives every moment and at the same time is becoming new. If you say that it is a unique being, you are right and if you say it is several beings, you are right. If you say that it is the same from the beginning of creation to the end of its being, you are right and if you say that he is getting new and changing into another thing, you are right. Yes, human being is developing every moment.

Mulla Sadra has graded the process of human growth: Human soul is in the plant degree when he is an embryo in his mother's womb because he has passed through the nature of the inanimate. Embryo is potentially an animal but actually a plant because at this time he does not have voluntary sense and movement, but due to having faculty and capacity towards animal degree, it is more superior and higher than other plants. As a child leaves his mother's womb and before reaching puberty, it is at the same degree as animal souls. Then, his animal soul changes into rational soul, that is, he can comprehend universal concepts by means of thinking and contemplating. So, if this capacity improves in him, he will get into the degree of sacred soul and actual intellect. Human soul reaches this stage at the age of forty. This is the time of growth and the emergence of rational maturity and a background to reach spiritual strength (Mulla Sadra 1391H). Then, from Mulla Sadra's point of view, the evolution of human being is not merely limited to intellectual evolution, but he is able to reach a kind of important maturity which is spiritual one.

So far, it has become clear that Mulla Sadra believes in three kinds of relationship between body and soul: at the stage of origination, soul is completely dependent on the body and human being whose material faculties are growing in this stage, is, actually, an animal and, potentially, a human being. This stage stretches from the time of soul origination up to the age of forty when the faculty of speculative reason gets actualized. From this time on, the body gets weak and soul becomes strong. The third stage is spiritual maturity; it is the time when speculative reason gets actualized and changes into abstract intellect. Human being, therefore, is always becoming unintentional and this is what some great philosophers like Ibn Sina have been unaware of (Mulla Sadra 1391H). Giving a respond to the question of what cause or causes 
give rise to changes in animal and creation of human soul, due to the lack of scientific knowledge at his time, only some points are mentioned by Mulla Sadra. The serious response to this question dates back to the studies made by biologists from the seventeenth century onward. Have environmental factors and geographical effects, as Lamarck says, developed the life of living thing, and created features in it to make them heritable (Villee 1979)? Some words of Mulla Sadra points to this factor that the place of living has been effective on animal to become human being. As he states that the peoples of lowest level who live in the far north or far south of the civilized world, are with less capacity to understand and reach ethical virtues. Those who live in the middle of the earth possess more speculative capacity to understand and acquiring more ethical virtues. In order to explain the natural choice better, Darwin has pointed to the function of human choices in changing different ways of growing flowers, plants and domestic animals. He believes that nature does the same thing as the grower does among domestic animals, i.e. omission and amendment through variety and natural choice. Mulla Sadra states that it is effective for horses and dogs to be trained by human being in order to make them close to the human horizon (Mulla Sadra 1381).

\section{Challenges Opposing Mulla Sadra's Theory of Evolution}

The challenges might result from Mulla Sadra's theory of evolution can be categorized into five groups: God, human being, science, philosophy and the Quran. One might misunderstand from Mulla Sadra's explanation on human creation that because he has mentioned substantial movement as the cause of human creation, he has decreased the function of God in human creation. Criticizing the theory of evolution, traditionalists say: "according to this theory the Creator has no role in the appearance of all various types and historical improvement of the world. There is no aim and objective for this evolution and improvement, but it happens because of conflict. This theory has an important contribution and role in the annihilation of the meaning and concept of the sacredness of God's creation" (Nasr 1374H). Rejecting this critique, we can reply that there is no contradiction between the regularization of creation and God's being cause of causes or existential dependence of all creatures on God. Besides, this theory can offer a new explanation on the wise action of God in making the creation purposive, because, in fact, this idea is an explanation for God's Providence and shows that God has not created the world purposeless, useless, and indecisive. According to martyred Mutahhari $(1361 \mathrm{H})$ : "the theory of evolution, more than before, shows the interference of a managing, directing and advising power in the creation of living things and is offering the principle of purposiveness".

One may misunderstand from Mulla Sadra's idea on the human creation that human nobility and essential worth and his being God's successor is really doubtful, because a creature evolved from animals is worthless. How can Mulla Sadra, who has emphasized on the similarity between human being and animals like monkey, keep the least reverence of human being, as previous philosophers did? The previous philosophers introduced human soul as an eternal and divine being. They kept a distinction between body and soul, but Mulla Sadra has ruined the boundary and has created a unity, not integration, among them. It can be said in reply that there is no contradiction between Mulla Sadra's theory and human nobility and essential value, as the holy Quran also says that human being is from dust, fetid mud or sperm and he is explained in this way: "There surly came over a man a period of time when he was a thing not worth mentioning" (76:1). However, Quran mentions his nobility and being God's successor. In addition, Mulla Sadra emphasizes on rational, spiritual, and abstract evolution of soul and its nobility. 
It might be said that, firstly, Mulla Sadra's theory based on his philosophy i.e. 'substantial movement' is correct, but he should not have discussed the creatures' natural structure and intervene empirical sciences. Secondly, Mulla Sadra's discussion is not limited to creation and some may abuse that natural discussion and expand the issue of evolution into other issues like social, political, ethical and economical sciences to question human traditional dignity in these realms. Whereas, we should not get value result out of substantial movement and consider perfect and evolution the same. It can be answered that, firstly, Mulla Sadra discussed natural sciences when different sciences were not specialized and their specialists were not distinct. Secondly, the value of judgments is evaluated with human reasons and his final perfection. Moral values include their own principles and nowadays, non-scientific generalizations of the nineteenth century have few advocates among scientists.

Criticizing Mulla Sadra's theory, one can say: first, the theory of evolution is not a certain philosophical principle (Tabatabai 1366H). Species evolution is, finally, uncertain conjecture and is a theory which might be replaced by another one someday. Secondly, whatever the scientists have found, so far, is the development in one species which is always transferred from one feature to another feature, but it does not convey from one species to another species (Tabatabai 1396H). Third, if the theory of evolution is approved, we can assume human species as an independent being and irrelevant to other creatures and believe in the development and evolution in his degree not in his essence, because we have not observed a monkey changing into human being, but the only development observed so far has been in the properties, requirements and accidents of the human beings (Tabatabai 1394H). It can be said in reply that, first, none of the scientists have claimed that the theory of evolution is a general philosophical principle and no scientist believes in the perfectness of this theory. Second, if the theory of evolution from science point of view is not definite and certain, it is from view point of Mulla Sadra's principles is definite and certain. According to substantial moment, no species is stable in the natural creatures, but every moment it is in a different condition and more perfect, comparing to the previous moment. Imam Khomeini said: "everybody has independently a limit of existence and is an independent species; this person has a different species from that one (Ardabili 1390, v. 1). If we, therefore, approve evolution as a philosophy principle and do not believe in stability for species, there is no exception with this general principle, as Mulla Sadara says: "whatever can be referred to as natural being has a movement from weakness to intensity and there is no meaning in a movement from intensity to weakness" (Tabatabai 1362H).

One of the serious challenges of the theory of evolution is its contradiction with the implications of the holy Quran. God has said in the holy Quran that He created man with His hands and out of dust and inspired (bowed sprit) into him. The creation of Adam, the prostration of angels toward him, settling in the heaven and his fall, all and all is implications of the Holy Quran which is not compatible with Mulla Sadra's words. Allameh Tabatabai asserts that we can understand from the verses of Quran that Adam and Eve did not connect with the creatures before and like themselves, but they were suddenly created with no previous trace (Tabatabai $1394 \mathrm{H}$ ). He repeats his words that the present-day human generation results from Adam and Eve who were not born to any parents, but whom were made out of dust (Tabatabai $1396 \mathrm{H}$ ). In order to answer, it can be said that as 'creating with two hands of God' does not mean 'God has hands' and 'blowing sprit' does not mean 'God has mouth', creation out of dust also does not mean direct creation from dust. After explaining natural process and material improvement, God says in the Quran: "Then, we caused it to grow into another creation, so blessed be Allah, the best of the creators" (Tabatabai 1394H). It explains a substantial difference in human being between the previous stage in which he possesses only sense and imagination, and the next stage in which he is with intellect. This is the creation of an intellectual being that deserves praise. This might be the reason that the way in which Allameh Tabatabai speaks in his 
interpretation in volume sixteen is not as serious and severe as volume four. He reconciles in the sixteenth volume and says: Quran's verses are not explicit in direct creation of Adam and Eve out of dust and there is no explicit tradition on this issue in order not to interpret the verses otherwise. Besides, it is not necessary from religious point of view to believe in the sudden creation. He continues that the Quran does not explain the manner Adam was created out of dust and it is not clear whether natural factors were involved or there were extraordinary factors which caused human creation (Tabatabai 1396H). In addition, Allameh points out some traditions which assert that there were human or human-like creatures before the creation of Adam and Eve (Tabatabai 1393H). Therefore, together with martyred Mutahhari, we can believe in evolution through following the Quran, as he said: if it is scientifically certain that human being had animal ancestors, it becomes obvious that the Quran has symbolically narrated the story of Adam and has not wanted to use scientific language (Mutahhari 1361H). It is concluded from what was mentioned in this paper that Mulla Sadra's philosophical doctrine on substantial movement of human soul is not only compatible with the theory of biological evolution but also it is its requirement. In order to explain the compatibility and harmony of Mulla Sadra's philosophical opinions with evolution theory, Mulla Sadra's doctrine is first discussed in this paper.

In the past, it was thought that the components of nature, consisting of the inanimate, plants, animals and human beings had been the same from the time of creation by the Almighty. The contemporary scientists, because of their observations, had reached transformism, based on which the whole world of nature is in development and change, so that the whole universe or parts of it is always subject to constant change and through the process of development, number, complexity and variety of the components of the world are increasing. The doctrines of the philosophers like Plato, Aristotle, Avicenna and Sheikhe Ishragh cannot philosophically explain this theory because they believe in reality and actuality of species. The theory of evolution not only is compatible with the Mulla Sadra's philosophical geometry, but one who has accepted Mulla Sadra's philosophical geometry cannot disagree with the evolution of human and other creatures.

The principality of existence, the analogical unity of existence, the substantial movement and gradual increase in intensity of existence, are the main foundations of Mulla Sadra's philosophy. The first three are a justification of the fourth one which is the evolutional movement of natural creatures. Mulla Sadra believes that existence is concrete and fundamental reality. Whatever, therefore, is in reality is existence. Existence is analogical and has filled the whole universe. The creatures we know in the world of nature, are degrees of existence. According to Mulla Sadra's view substantiational movement, nature is essentially changing and movement is in its essence. The world of nature is a single continuous thing which ascends from its own infertility to its own superiority like a child's reaching puberty and becoming perfect as an adolescent. Plants evolve because of the substantial movement and human beings manifest because of the evolution of animals. Species or different degrees of nature are numerous variations of one existence and as the whole nature possesses different transformations, Mulla Sadra believes in three (material, intellectual and spiritual) transformations of human being. It was, finally, shown that the attempts of scientists is along with explaining the modality of this philosophical evolution and have explained Mulla Sadra's philosophical theory. It also became obvious that the criticism of evolution critics is unreasonable and this view not only is not contradictory to the religious teachings but is an explanation of the wisdom and providence of God. 


\section{References}

Ardabili, Abdulghani. 1390H. Taghrirate Falsafehe Imam Khomeini Imam Khomeini's Philosophy Statements. $3^{\text {rd }}$ ed. Tehran: Institute for Publication of Imam Khomeini's Works.

Bowler, P. J. 2000. Evolution. In Gary B. Ferngren (ed.). The History of Science and Religion in the Western Tradition: An Encyclopedia, pp. 524-532. New York: Garland Publishing.

Campbell, B. G. 1971. Human Evolution: An Introduction to Man's Adaptation. London: Heinemann Educational Books Ltd.

Darwin, C. 2004. The Origin of Species. $6^{\text {th }}$ ed. (online) https://www.andrew.cmu.edu/user/jksad egh/A\%20Good\%20Atheist\%20Secularist\%20Skeptical\%20Book\%20Collection/Charle s\%20Darwin\%20-\%20The\%200rigin\%20 of\%20Species\%20-\%206th\%20Edition.pdf.

Encyclopedia of the Islamic World. 1383H. Vol. 8. Tehran: The Institute of Islamic Encyclopedia.

Holy Quran. 1994. Translated by M. H. Shakir. Qum: Ansarian Publications.

Ibn Miskawayh, Ahmad ibn Muhammad ibn Ya'qub. 1338H. Al-Fawz al-Asghar. Qum: Ayate Ishraq Publication.

Ibn Miskawayh, Ahmad ibn Muhammad ibn Ya'qub. 1365H. Tahdhib al-Akhlaq wa Tathir alA'raq (Purification of Morality and Refinery of Originality). Qum: Bidar Publication.

Ikhwan al-Safa. 1995. Rasail lkhwan al-Safa (Treatises of the Brethren of Purity). Vol. 2. Paris: Aluvidat Publication.

Mussaheb, Gholamhossein. 1380H. Encyclopedia of Persian. Vol. 2. Tehran: Amir Kabir Publication.

Mutahhari, Murtaza. 1361H. Elale Gerayesh be Madigari (Reasons of Tendency toward Materialism). Qum: Islamic Publication Bureau.

Mulla Sadra, Muhammad Ibn Ibrahim. 1378H. Risalah fi Alhodu (Treatise on Contingency). Edited by Hossein Mousavian. Tehran: Sadra Islamic Philosophy Foundation.

Mulla Sadra, Muhammad Ibn Ibrahim. 1380H. Al-Hikmat al-Muta 'aliyah fi al-Asfar al-Arba'ah (The Transcendent Theosophy in the Four Journeys). Vol. 2. Edited by Maqsood Mohammadi. Tehran: Sadra Islamic Philosophy Foundation.

Mulla Sadra, Muhammad Ibn Ibrahim. 1381H. Al-Hikmat al-Muta 'aliyah fi al-Asfar al-Arba'ah (The Transcendent Theosophy in the Four Journeys). Vol. 5. Edited by Mohammadzadeh. Tehran: Sadra Islamic Philosophy Foundation.

Mulla Sadra, Muhammad Ibn Ibrahim. 1383Ha. Al-Hikmat al-Muta 'aliyah fi al-Asfar al-Arba'ah (The Transcendent Theosophy in the Four Journeys). Vol. 8. Edited by Ali Akbar Rashad. Tehran: Sadra Islamic Philosophy Foundation.

Mulla Sadra, Muhammad Ibn Ibrahim. 1383Hb. Al-Hikmat al-Muta 'aliyah fi al-Asfar al-Arba'ah. (The Transcendent Theosophy in the Four Journeys). Vol. 3. Edited by Maqsood Mohammadi. Tehran: Sadra Islamic Philosophy Foundation.

Mulla Sadra, Muhammad Ibn Ibrahim. 1391H. Al-Sahawahid al-Rububiah (The Heavenly Evidences). Edited by Mustafa Muhaqeq Damad. Tehran: Sadra Islamic Philosophy Foundation.

Nasr, Hussein. 1374H. Javane Musalman va Dunyaye Mutajadded (Young Muslims and Modernized World). Translated by Murtaza Asadi. Vol. 2. Tehran: New Design Publication.

Prothero, D. R. 2011. The Fossils Say Yes. In Sara Fletcher Harding \& Nancy Morvillo (eds.) Religion and Science: Critical Concepts in Religious Studies. Vol. 3. New York: Routledge.

Tabatabai, M. H. 1362H. Al-Nihayah al-Hikmah (The End of Wisdom). Qum: Al-Nashr al-Islami Publication.

Tabatabai, M. H. 1366H. Usole Falsafe va Raveshe Realism (Philosophy Principles and Manner of Realism). Qom: Islamic Publications Bureau. 
Tabatabai, M. H. 1393H. Al-Mizan fi Tafsir al-Quran (Measurement in Interpreting the Quran). Vol. 1. Beirut: Al-Alami Lelmatbouat Institute

Tabatabai, M. H. 1394H. Al-Mizan fi Tafsir al-Quran (Measurement in Interpreting the Quran). Vol. 4. Qom: Ismailian Press.

Tabatabai, M. H. 1396H. Al-Mizan fi Tafsir al-Quran (Measurement in Interpreting the Quran). Vol. 16. Tehran: Dar al-Kutub al-Islamiah.

Villee, C. A. \& Dethier, V. G. 1979. Biological Principles and Processes. London: W.B. Saunders Company. 